\title{
Biotechnologies in the creation of black and red rice varieties for functional nutrition
}

\author{
Yulia Goncharova ${ }^{1,3, *}$, Olesya Bragina $^{1}$, Sergey Goncharov ${ }^{2}$, and Evgeniy Kharitonov ${ }^{1}$ \\ ${ }^{1}$ FGBNU "Federal Research Center for Rice", 350921 Krasnodar, Belozerny 3, RF \\ ${ }^{2}$ Kuban State Agrarian University, 350000 Krasnodar, RF \\ ${ }^{3}$ OOO "Aratai", "Skolkovo", 143026 Moscow, RF
}

\begin{abstract}
Resistant varieties allow to reduce water consumption, application of pesticides and herbicides during their production, which is necessary for the development of energy-efficient and organic cultivation technologies. Another task facing breeders is the creation of black-grain and red-grain rice varieties containing up to 20 times more antioxidants than white-grain rice varieties for functional nutrition. To solve these problems, systems of molecular markers have been developed to control the inclusion of target loci in the cultivar genotype. The production of rice varieties with colored pericarp in Russia is associated with the inclusion in the genotype of created varieties genes that determine drought resistance, due to the lack of irrigation water in most rice-growing regions. To reduce the complexity of creating varieties of functional direction with given characteristics, markers linked to genes of interest are grouped into multiplex complexes presented in the work. They simultaneously control both the adaptability and the nutritional value of the material. Four multiplex complexes control 11 loci that determine the content of micro and macro elements. The first one controls the genes that determine the content of $\mathrm{Mn}, \mathrm{Ca}$ on chromosome 3 and $\mathrm{Zn}$ on the eighth chromosome. The second controls two genes that determine the content of iron (on chromosomes 6 and 8 ) and manganese on the tenth chromosome. The third helps to identify polymorphism at the loci that determine the content of $\mathrm{Zn}, \mathrm{P}, \mathrm{K}$ and other traits that determine the nutritional value on chromosomes 5, 6, 8. Five complexes help to track the inclusion in the genotype of 13 loci that determine the formation of traits associated with the adaptability of rice samples.
\end{abstract}

\section{Introduction}

Until recently, productivity was the only criterion for the regionalization of crop varieties, but now all over the world people prefer products with medicinal properties produced using organic technologies [1-4]. In a number of studies, markers have been identified that determine an 8-fold increase in the content of micro and macroelements in red and black rice varieties [5-8]. Varieties for organic technologies should be distinguished by a whole range of traits that allow them to more effectively deal with biotic and abiotic stresses, which makes it possible to reduce the application of fertilizers, pesticides and herbicides during their production [9-11].

Another problem for the Russian organic rice production is the lack of water in the territories where the production of such varieties is planned. A number of chromosomal regions have been established that determine adaptability to drought of various types in rice samples; however, such studies have not been carried out in Russia [12-16]. The aim of the study is to create a system of markers to control the inclusion of a complex of traits that determine nutritional value, productivity and adaptability in the created varieties.

\section{Materials and methods}

As a material for research, we used 25 regionalized and promising varieties of Russian selection from the collection of the Federal State Budgetary Scientific Institution "FNTs Rice". Among them were varieties of different quality: short-grain, medium-grain, large-grain, long-grain, with various culinary and technological properties. The objectives of the study were to identify the loci that determine the productivity of domestic rice varieties when exposed to drought and high temperatures, usually accompanying it. Plants were grown in a growing area until the flowering phase. A sample of 20 plants of the cultivar per variant of the experiment, 10 plants per vessel were grown on the optimal background of mineral nutrition, Then the vessels were brought into the chambers of the artificial climate with different temperatures and water regime.

According to the results obtained, varieties were divided into groups with different resistance to stress. The polymorphism of these varieties was studied using 100 markers distributed across all rice chromosomes. We used markers associated with loci that control adaptability and productivity. Rice DNA was isolated

\footnotetext{
* Corresponding author: yuliya_goncharova_20@mail.ru
} 
Table 1. Influence of drought and high air temperature on productivity characteristics of rice varieties.

\begin{tabular}{|c|c|c|c|c|c|c|}
\hline \multirow[b]{2}{*}{ Сорт } & \multicolumn{2}{|c|}{ Weight of 1000 grains, g. } & \multirow[b]{2}{*}{$\begin{array}{l}\text { The range of } \\
\text { variability, } \%\end{array}$} & \multicolumn{2}{|c|}{ Empty grain, $\%$} & \multirow[b]{2}{*}{$\begin{array}{l}\text { The range of } \\
\text { variability, } \%\end{array}$} \\
\hline & $\begin{array}{c}\text { Artificial climate } \\
\text { chamber, } \\
\text { t } 35^{\circ} \mathrm{C} \\
\end{array}$ & control & & 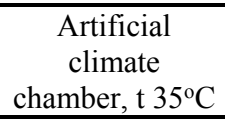 & control & \\
\hline VNIIR 8242 & 12.3 & $22.5^{*}$ & 45.2 & 95.6 & $32.6^{*}$ & 63 \\
\hline Ametist & 18 & $24.1 *$ & 25.4 & 40.1 & $19.0^{*}$ & 21.2 \\
\hline Atlant & 20.8 & 21.7 & 4.5 & 59.9 & $18.1^{*}$ & 41.8 \\
\hline Boyarin & 21.4 & 23.6 & 9.5 & 64.6 & $23.3^{*}$ & 41.3 \\
\hline Garant & 15.8 & $22.9^{*}$ & 31 & 91.2 & $11.6^{*}$ & 79.6 \\
\hline Druphniy & 18.5 & 20.6 & 8.2 & 47.5 & 40.5 & 7 \\
\hline Shemchug & 14.8 & $21.9 *$ & 32.2 & 48.6 & $19.7 *$ & 29 \\
\hline Izumrud & 19.3 & $22.9^{*}$ & 15.5 & 76.6 & $33.6^{*}$ & 43 \\
\hline Kasun & 19 & $23.2^{*}$ & 18.1 & 75.1 & $39.2^{*}$ & 35.9 \\
\hline Kurchanka & 22.7 & 23.1 & 1.9 & 79.1 & $53.7 *$ & 25.4 \\
\hline Liman & 16.7 & $22.7 *$ & 26.4 & 40.1 & $21.6^{*}$ & 18.5 \\
\hline Narsiss & 15 & $28.8^{*}$ & 47.9 & 98.3 & $65.0^{*}$ & 33.4 \\
\hline Novator & 15.2 & $21.6^{*}$ & 29.4 & 62.1 & 50.7 & 11.4 \\
\hline Pavlovskiy & 25.6 & 26.7 & 4.2 & 42.5 & 31.1 & 11.4 \\
\hline Regul & 18.9 & $23.3^{*}$ & 19.1 & 70.2 & $37.9^{*}$ & 32.3 \\
\hline Sadko & 20 & $23.0^{*}$ & 13 & 91.2 & $62.1^{*}$ & 29.1 \\
\hline Serpantin & 18.4 & $21.3^{*}$ & 13.8 & 46 & 40.8 & 5.2 \\
\hline Sneshinka & 18.8 & $23.6^{*}$ & 20.6 & 91.1 & $31.0^{*}$ & 60 \\
\hline Sprint & 17.9 & $22.9^{*}$ & 21.7 & 78.2 & $21.8^{*}$ & 56.3 \\
\hline Streles & 15.1 & $22.2 *$ & 31.9 & 62.8 & 64.2 & -1.4 \\
\hline Phakel & 21.7 & $24.5^{*}$ & 11.5 & 68.4 & $32.4^{*}$ & 36.1 \\
\hline Phontan & 21.1 & $23.9^{*}$ & 11.7 & 73.1 & $21.1^{*}$ & 52 \\
\hline Khazar & 13.8 & $20.9 *$ & 30.7 & 91.3 & $32.2 *$ & 59.2 \\
\hline Xankayskiy & 18.9 & $25.1^{*}$ & 24.9 & 90.4 & $29.1^{*}$ & 61.3 \\
\hline Yupiter & 16.7 & $20.1^{*}$ & 16.6 & 44.7 & $38.7^{*}$ & 6 \\
\hline Mean & 18.2 & $23.0 *$ & 20.6 & 69.2 & $34.8^{*}$ & 35.8 \\
\hline maximum & 25.6 & $28.8^{*}$ & 47.9 & 98.3 & $65.0^{*}$ & 79.6 \\
\hline minimum & 12.3 & $20.6^{*}$ & 1.9 & 40.1 & 11.6 & -1.4 \\
\hline
\end{tabular}

from rice seedlings and leaves. PCR parameters used in this experiment: 5 minutes at $94 \circ \mathrm{C}$ - initial denaturation, the following 35 cycles: 1 minute denaturation at $94^{\circ} \mathrm{C}, 1$ minute - primer annealing at 55 ${ }^{\circ} \mathrm{C}, 2$ minutes - synthesis at $72{ }^{\circ} \mathrm{C}$; its last cycle is 7 minutes at $72^{\circ} \mathrm{C}$. The PCR mixture included $40 \mathrm{ng}$ DNA $(2 \mu \mathrm{l}), 1 \mu \mathrm{l}(1 \mathrm{mM})$ deoxynucleotide triphosphates (dNTPs); $3.7 \mu \mathrm{l} \mathrm{H} 2 \mathrm{O} ; 1 \mu \mathrm{l}$ - buffer solution, $0.5 \mu \mathrm{l}$ (5 $\mu \mathrm{M})$ - each primer, $1 \mu \mathrm{l}$ (1.5 units) - Taq-polymerase, in a total volume of $10 \mu \mathrm{l}$. The amplification products were separated by electrophoresis in polyacrylamide gel at a voltage of $100 \mathrm{~V}$.

\section{Results and discussion}

According to the results of the experiment, the studied varieties were divided into groups with different resistance to stress (table 1).

The polymorphism of these varieties was studied using 100 markers distributed across all rice chromosomes. We used markers associated with loci that control adaptability and productivity. Some of the markers did not reveal polymorphism in the breeding

Table 2. Markers linked to loci that determine adaptability to drought in domestic rice varieties.

\begin{tabular}{|c|c|c|}
\hline Traits & $\begin{array}{c}\text { Markers reliably linked to a trait at the level of } \\
\text { significance } \\
0.05\end{array}$ & $\begin{array}{c}\text { Markers reliably linked to the trait at the } \\
\text { level of significance } \\
0.09\end{array}$ \\
\hline Empty grain & RM 25, RM 600, RM 6410, RM 289 & RM154,RM141,RM6024 \\
\hline Main panicle weight & RM104, RM509 & RM322,RM5707,RM289 \\
\hline Total spikelets & RM574, RM261, RM600, RM6410 & RM13 \\
\hline Weight of 1000 grains & RM509 & RM542,RM600,RM3276,RM5361,RM6811 \\
\hline Stem weight & RM240, RM542, RM600, RM5638 & RM6811,RM289 \\
\hline Chaff mass & RM245, RM140, RM242, RM261 & RM240,RM82,RM276,RM5707 \\
\hline Number of stems & & \\
\hline
\end{tabular}


Table 3. Marker multiplex complexes to reduce the complexity of studying drought adaptability population polymorphism.

\begin{tabular}{|c|c|c|c|}
\hline Marker & Repeating motif & Melting point & Amplification product size \\
\hline \multicolumn{4}{|c|}{ Multiplex complex 1} \\
\hline RM261 & С9CT8 & 55 & 125 \\
\hline RM574 & GA11 & 55 & 155 \\
\hline RM140 & CT12 & 55 & 261 \\
\hline \multicolumn{4}{|c|}{ Multiplex complex 2} \\
\hline RM25 & GA18 & 55 & 146 \\
\hline RM6410 & GAG8 & 55 & 177 \\
\hline RM5638 & AAG13 & 55 & 203 \\
\hline \multicolumn{4}{|c|}{ Multiplex complex 3} \\
\hline RM240 & CT21 & 55 & 132 \\
\hline RM82 & (TCT)11 & 55 & 186 \\
\hline \multicolumn{4}{|c|}{ Multiplex complex 4} \\
\hline RM154 & $(\mathrm{GA}) 21$ & 61 & 183 \\
\hline RM104 & GA9 & 61 & 222 \\
\hline \multicolumn{4}{|c|}{ Multiplex complex 5} \\
\hline RM5707 & $(\mathrm{AAT}) 21$ & 50 & 139 \\
\hline RM3276 & $(\mathrm{CT}) 13$ & 50 & 163 \\
\hline RM6024 & $(\mathrm{CCG}) 8$ & 50 & 178 \\
\hline
\end{tabular}

material; later they were excluded from the analysis.

As a result of our work, we have identified a number of markers reliably (according to the results analysis of variance) linked to the loci that determine the adaptability to drought in domestic rice varieties, shown in Table 2.

The search for loci that determine trait in the selected chromosomal regions in information databases (www.gramene.org.) showed that in most of identified loci, earlier somehow determine presence of genes that was established formation of drought resistance trait.

Using polymorphic markers, selected according to the reliability of their influence on the formation of drought resistance in domestic rice varieties, multiplex complexes have been developed to reduce the complexity of studying population polymorphism (Table 3).

For additional marker control of nutritional value retention, complexes of SSR markers were also developed, they are shown in Table 4.
The first one controls the genes that determine the content of $\mathrm{Mn}, \mathrm{Ca}$ on chromosome 3 and $\mathrm{Zn}$ on the eighth chromosome. The second controls two genes that determine content of iron (on chromosomes 6 and 8) and manganese on the tenth chromosome. The third helps to identify polymorphism at the loci that determine the content of $\mathrm{Zn}, \mathrm{P}, \mathrm{K}$ and other traits that determine the nutritional value on chromosomes $5,6,8$.

\section{Conclusion}

1. The production of black and red rice varieties containing up to 20 times more antioxidants in Russia is associated the inclusion in genotype of created varieties loci that determine drought resistance due to the lack of irrigation with water in most rice-growing regions.

2 . The complexity of creating varieties functional direction with the given characteristics should be reduced by the multiplex complexes of molecular marker

Table 4. Complexes of markers for studying nutritional value.

\begin{tabular}{|c|c|c|c|}
\hline Marker (chromosome) & $\begin{array}{c}\text { Melting } \\
\text { temperature, } \mathrm{C}^{0}\end{array}$ & $\begin{array}{l}\text { Amplification product } \\
\text { size }\end{array}$ & Determined feature \\
\hline \multicolumn{4}{|c|}{ Multiplex complex 1} \\
\hline RM 227 (3) & 55 & 106 & $\mathrm{Mn}, \mathrm{Ca}$ \\
\hline RM 25 (8) & 55 & 146 & $\mathrm{Zn}$ \\
\hline RM $126(8)$ & 55 & 172 & nutritional value \\
\hline \multicolumn{4}{|c|}{ Multiplex complex 2} \\
\hline RM 590 (10) & 55 & 137 & $\mathrm{Mn}$ \\
\hline RM $259(8)$ & 55 & 162 & $\mathrm{Fe}$ \\
\hline RM 53(6) & 55 & 182 & $\mathrm{Fe}$ \\
\hline \multicolumn{4}{|c|}{ Multiplex complex 3} \\
\hline RM 30 (6) & 55 & 105 & nutritional value \\
\hline RM $13(5)$ & 55 & 141 & nutritional value \\
\hline RM $440(8)$ & 55 & 169 & $\mathrm{Zn}, \mathrm{P}, \mathrm{K}$ \\
\hline \multicolumn{4}{|c|}{ Multiplex complex 4} \\
\hline RM $256(8)$ & 55 & 127 & nutritional value \\
\hline RM $574(5)$ & 55 & 155 & $\mathrm{Fe}$ \\
\hline
\end{tabular}


presented in the work. They simultaneously allow to control both adaptability and nutritional value. Four multiplex complexes control 11 loci that determine the content of micro and macroelements, and 5 complexes help to track the inclusion in the genotype 13 loci that determine the formation of traits associated with adaptability in rice samples.

This work was financially supported by the Russian Science Foundation No. 19-16-00064.

\section{References}

1. J. Moyer, K. Nichols, V. Bhosekar, Asian Journal of Science and Technology, 8 (4), 4628-4634 (2017)

2. E.A. Fedulova, A.V. Medvedev, P.D. Kosinskiy, S.A. Kononova, N. Pobedash, Foods and Raw Materials, 4 (1), 154-162 (2016)

3. J. Chavas, J. Posner, J. Hedtcke, Agronomy Journal, 101, 288-295 (2009)

4. Yu.V. Fotev, V.F. Pivovarov, A.M. Artemyeva, I.M. Kulikov, Yu.K. Goncharova, A.I. Syso, N.P. Goncharov, V.J. of Genetics and Breeding, 22 (7), 776-783 (2018)

5. K. Lu, L. Li, X. Zheng, Z. Zhang, T. Mou, Z. Hu, J. Genet, 87, 305-310 (2008)

6. M. Zhong, L. Wang, J. Yuan, L. Luo, C. Xu, Y.Q. He, Rice Sci., 18 (3), 187-195 (2011)

7. A. Mahender, A. Anandan, S. Kumar, P. Pandit, E. Pandit, Springer Plus, 5 (2016)

8. M.L. Guerinot, D.E. Salt, J. Theor Appl. Genet, 127, 137-165 (2014)

9. Yu.K. Goncharova, E.M. Kharitonov, V. J. of Genetics and Breeding, 19 (2), 47-54 (2015)

10. Yu.K. Goncharova, E.M. Kharitonov, Ye.A. Malyuchenko, N.Yu. Bushman, V. J. of Genetics and Breeding, 22 (1), 79-87 (2018)

11. Yu.K. Goncharova, E.M. Kharitonov V.A. Sheleg, Journal of Agricultural biology, 52 (3), 515-525 (2017)

12. K.R. Trijatmiko, S.K. Prasetiyono, M.J. Thomson, C.M. Vera Cruz, S. Moeljopawiro, Mol. Breed., 34, 283-295 (2014)

13. N. Sandhu, A. Kumar, Agron. J., 7, 27 (2017)

14. U. Bhattarai, P.K. Subudhi, Map. Gene, 669, 6976 (2018)

15. J. Solis, A. Gutierrez, V. Mangu, E. Sanchez, R. Bedre, Front. Chem., 5 (2018)

16. S. Saikumar, K.P. Gouda, A. Saiharini, C.M. Varma, O. Vineesha, G. Padmavathi, V.V. Shenoy, Field Crops Res., 163, 119-131 (2014)

17. Electronic resource Available at: http://www.gramene.org 